\title{
Status Kesehatan Pasar Ditinjau dari Aspek Sanitasi dan Perilaku Hidup Bersih Sehat (PHBS) pada Pasar Ciputat dan Pasar Modern BSD Kota Tangerang Selatan
}

\author{
Health Status of Market Aspects of Sanitation And A Clean Healthy Living Behaviours \\ (PHBS) In Ciputat Market and Market Modern BSD South Tangerang City \\ Rusman Efendi $^{1 *}$, Jihan Nada Alya Syifa ${ }^{1}$ \\ ${ }^{1}$ Program Studi Kesehatan Masyarakat, Fakultas Kesehatan Masyarakat \\ Universitas Muhammadiyah Jakarta \\ *korespondensi : rusman.efendi@gmail.com
}

\begin{abstract}
The less market seen from the aspect of good sanitation and health behaviour of traders, managers and visitors can be a source of the disease. One way to break the direct or indirect contacts that can occur in a market environment that is need for the implementation of a good market environment sanitation in accordance with the guidelines of the healthy market Kepmenkes Number 519/Menkes/SK/VI/2008. The purpose of this research is to know the health status of the market in terms of Sanitation and market aspects of Ciputat and markets Modern BSD. This research was conducted in may 2018. This research is the kind of research kuantitif with a descriptive observational approach by using a cross sectional study design, which is based on checklist No. 519 Kemenkes the year 2008 about the market Healthy. Health status of Ciputat Market aspects of sanitation categorized less with a score of 1484 or $51.5 \%$, yet in the aspect of PHBS Ciputat Market categorized less well with a score of 1400 or $46.7 \%$ while Modern BSD market's Health Status in terms of sanitary aspects categorized both by a score of 2500 or $86.8 \%$ but in the aspect of Modern BSD market PHBS categorized both by a score of 2350 or $78.3 \%$. The good health status of the Modern BSD market and Ciputat Market assessed aspects of sanitation and clean living and healthy behaviors (PHBS), on the assessment of the two aspects of the modern market of sanitary aspects and PHBS, market manager for Advice to undertakings leasehold improvements to market better.
\end{abstract}

Keywords : Market, Health, Sanitation, Healthy And Clean Life Behavior

\section{Pendahuluan}

Pasar termasuk tempat umum yang merupakan sarana dimana orang banyak terkumpul dan mengadakan interkasi atau hubungan dengan sesamanya, salah satu bentuk interaksi tersebut bertemunya para penjual dan pembeli. Pasar berdasarkan jenisnya terbagi dua yaitu pasar tradisional dan pasar modern, pasar tradisional biasanya dibangun dan dikelola oleh pemerintah maupun kerjasama swasta, dan proses jual beli barang dilakukan dengan tawar menawar sedangkan pasar modern merupakan pasar yang dikelola dengan manajemen modern dan umumnya terdapat dikawasan perkotaan (1).

Pada umumnya pasar tradisional mempunyai kondisi yang buruk, bahkan dari segi sanitasinya memiliki masalah seperti ketersedian air yang tidak mencukupi, sistem pengelolaan sampah yang tidak baik. Pasar yang kurang diperhatikan dari aspek kesehatan dapat menjadi sumber perkembangbiakkan penyakit. Hal ini dapat terjadi sebagai akibat menumpuknya sampah dan segala jenis kotoran yang telah membusuk, tidak adanya selokan/drainase dan kondisi bangunan yang tidak memadai, kondisi yang kurang sehat ini menjadi alur penularan penyakit dari satu orang keorang lain baik melalui kontak langsung maupun tidak langsung (2)

Tuntutan masyarakat akan pasar sehat dan pelayanan yang lebih baik semakin tinggi, oleh sebab itu pengelolaan "Pasar Sehat" perlu terus menerus diupayakan melalui Sanitasi dengan menitikberatkan pada berbagai faktor lingkungan yang mungkin mempengaruhi derajat kesehatan masyarakat . pasar sehat yang tidak terwujud dengan baik adalah masalah kesehatan lingkungan, hal ini disebutkan 
dalam jurnal sanitasi pasar di Nigeria yang menggambarkan pasar Benin, Nigeria yang lumrah dijumpai tumpukkan sampah dan binatang vector penular penyakit menjadi penyebab tingginya angka malaria dan diare (3).

Berdasarkan hasil penelitian yang dilakukan di pasar gampong ujong kalak kecamatan johan pahlawan kabupaten aceh barat, kondisi pasar bina usaha sangat jauh dari pasar yang sehat dari kondisi sanitasi pembuangan air limbah kotoran hewan seperti kotoran ayam, bebek dan kotoran ikan tidak bersih dan sangat jauh dari namanya pasar sehat sehingga mudah terjangkit penyakit, kondisi sanitasi yang tidak mengalir dan terendamnya air akan berkembanngbiaknya nyamuk sehingga mudah terjangkit penyakit seperti malaria dan kondisi sanitasi yang di genangi oleh air kotor dapat mengakibatkan diare akibar dari lalat yang hinggap pada kotoran yang terdiri ditempat sembarang tempat seperti makanan yang dijual di pasar (4).

Pada observasi pendahulu di pasar ciputat terlihat kotornya lingkungan pasar akibat sampah sudah tertumpuk dan terlihat juga air lindi di jalan membuat jalan licin, sementara dalam program pengembangan kesehatan pasar dikenal istilah "pasar acuan" yaitu pasar yang menjadi contoh pengembangan program pasar sehat, pasar acuan yang paling dekat dari pasar acuan adalah pasar yang dulunya adalah pasar tradisional namun sekarang sudah berubah, pasar ini pada 2011 menjadi tempat acara pencananggan hari pasar bersih nasional, pasar ini adalah pasar modern BSD city (5).

Dan Terkait besarnya jumlah populasi nasional maupun peran pasar bagi masyarakat dan kemungkinan pasar menjadi tempat wabah penyakit menular, maka penting kiranya untuk memperhatian aspek kesehatan dari pasar iru sendiri, Kondisi pasar yang tidak sehat didukung oleh posisi sanitasi yang sangat mempengaruhi pedagang dalam berinteraksi berjualan karena sanitasi mempunyai hubungan yang erat dan tidak dapat dipisahkan antara satu dengan yang lain, hygiene dan sanitasi merupakan usaha kesehatan masyarakat yang bertujuan untuk mencegah terjadinya penyakit pada manusia.

Berdasarkan latar belakang tersebut peneliti melakukan penelitian untuk mengetahui perbandingan penerapan Keputusan Menteri Kesehatan Republik Indonesia nomor 519/MENKES/SK/VI/2008 (6), tentang pedoman penyelenggaraan pasar sehat di pasar Ciputat dan Pasar Modern BSD. Penelitian ini bertujuan untuk mengetahui status kesehatan pasar pada aspek sanitasi dan Perilaku Hidup Bersih dan Sehat (PHBS) pasar ciputat dan pasar modern BSD di kota tangerang selatan.

\section{Metode Penelitian}

Penelitian ini merupakan jenis penelitian kuantitatif dengan pendekatan observasional deskriptif untuk mendapat gambaran status kesehatan pasar pada aspek sanitasi dan Perilaku Hidup Bersih dan Sehat (PHBS) yang berpedoman pada checklist Kemenkes No. 519 Tahun 2008 tentang pasar sehat (6). Penelitian dilakukan di Pasar Ciputat dan Pasar Modern BSD yang terletak di kota Tangerang Selatan, Provinsi Banten, pada bulan Maret-Mei 2018. Analisis dilakukan menggunakan Pedoman Kepmenkes 519/MENKES/SK/VI/2008 tentang Pasar Sehat dengan cara mencocokan kriteria yang tercantum pada standar dengan kenyataan sebenarnya di lapangan yang didapatkan melalui observasi, pengukuran langsung dan wawancara tidak terstruktur.

\section{Hasil}

Penilaian Status Kesehatan Pasar Dilakukan Sesuai Dengan Pedoman Pasar Sehat Kepmenkes Nomor 519/MENKES/SK/VI/2008 Pada aspek sanitasi dan perilaku hidup bersih dan sehat (PHBS) di Pasar Ciputat Dan Pasar Modern BSD, nilai maksimum untuk status kesehatan pasar sebesar 9.830 dimana setiap variabel memiliki nilai maksium yang berbeda-beda yang dikategorikan menjadi 3 kategori yaitu: Baik (75\%-100\%) dari nilai maksimum variabel, cukup (60\%-74\%) dari nilai maksimum variabel dan kurang $(<60 \%)$ dari nilai maksimum variabel.

\section{Sanitasi}

Penilaian sanitasi pasar dilakukan dengan cara observasi dan wawancara tidak terstuktur. Yang menjadi aspek penilaian status kesehatan pasar pada aspek sanitasi adalah 1). Air Bersih, 2). Kamar Mandi dan Toilet, 3). Pengelolaan Sampah, 4). 
Drainase, 5). Tempat Cuci Tangan, 6). Binatang Penular Penyakit(Vektor), 7). Kualitas Makanan dan Bahan Pangan, 8).Desinfeksi Pasar

Table 1 Status Kesehatan Pasar Pada Aspek Sanitasi Pasar Ciputat dan Pasar Modern BSD Tangerang Selatan

\begin{tabular}{|c|c|c|c|c|}
\hline Pasar & $\begin{array}{c}\text { Skore } \\
\text { yang } \\
\text { didapat }\end{array}$ & $\begin{array}{c}\text { Skore } \\
\text { Maksimum }\end{array}$ & $\%$ & Kategori \\
\hline Ciputat & 1484 & 2880 & 51,5 & Kurang \\
\hline $\begin{array}{l}\text { Modern } \\
\text { BSD }\end{array}$ & 2500 & 2880 & 86,8 & Baik \\
\hline
\end{tabular}

Berdasarkan tabel 1 hasil penelitian pasar status kesehatan sanitasi didapatkan bahwa pasar ciputat dalam kategori kurang, sedangkan pasar modern BSD dalam kategori Baik. Lebih rincinya dilihat pada tabel 1.1 berikut ini :

Tabel 1.1 Skor Penilaian Sanitasi

Komponen Skor Penilaian
penilaian

\begin{tabular}{lcc}
\hline \multicolumn{1}{c}{ penilaian } & $\begin{array}{c}\text { Pasar } \\
\text { Ciputat }\end{array}$ & $\begin{array}{c}\text { Pasar } \\
\text { Modern } \\
\text { BSD }\end{array}$ \\
\hline Air Bersih & 360 & 360 \\
\hline $\begin{array}{l}\text { Kamar Mandi / } \\
\text { Toilet }\end{array}$ & 280 & $400^{*}$ \\
\hline $\begin{array}{l}\text { Pengelolaan } \\
\text { Sampah }\end{array}$ & 164 & 320 \\
\hline Drainage & 160 & 320 \\
\hline $\begin{array}{l}\text { Tempat Cuci } \\
\text { Tangan }\end{array}$ & 160 & $400^{*}$ \\
$\begin{array}{l}\text { Binatang } \\
\text { Penular } \\
\text { Penyakit/Vektor }\end{array}$ & 120 & 120 \\
\hline $\begin{array}{l}\text { Kualitas } \\
\text { Makanan dan } \\
\text { bahan pangan }\end{array}$ & 240 & 280 \\
\hline $\begin{array}{l}\text { Desiinfeksi } \\
\text { Pasar }\end{array}$ & 0 & $300^{*}$ \\
\hline $\begin{array}{l}\text { Keterangan : }{ }^{*} \text { Memenuhi Syarat } \\
\end{array}$
\end{tabular}

Berdasarkan tabel 1.2 hasil skor penilaian sanitasi pada 8 komponen penilaian didapatkan bahwa status kesehatan sanitasi pasar ciputat tidak memenuhi syarat pada semua kompenen penilaian sedangkan pasar modern BSD memenuhi syarat pada 3 komponen penilaian yaitu kamar mandi/toilet, tempat cuci tangan dan desiinfeksi pasar.

\section{Perilaku Hidup Bersih dan Sehat (PHBS)}

Penilaian sanitasi pasar dilakukan dengan cara observasi dan wawancara tidak terstukur. Yang pada aspek Perilaku Hidup Bersih Dan Sehat (PHBS) adalah 1).

Pedagang dan Pekerja, 2). Pengunjung, 3). Pengelola.

Tabel 2 Status Kesehatan Pasar Pada Aspek (PHBS) Pasar Ciputat Dan Pasar Modern BSD Tangerang Selatan

\begin{tabular}{|c|c|c|c|c|}
\hline Pasar & $\begin{array}{c}\text { Skor } \\
\text { yang } \\
\text { didapat }\end{array}$ & $\begin{array}{c}\text { Skor } \\
\underset{*}{\text { maksimum }}\end{array}$ & $\%$ & $\underset{\mathrm{ri}}{\text { Katego }}$ \\
\hline Ciputat & 1400 & 3000 & $\begin{array}{c}46 \\
7\end{array}$ & Kurang \\
\hline $\begin{array}{l}\text { Moder } \\
\text { n BSD }\end{array}$ & 2350 & 3000 & $\begin{array}{c}78, \\
3\end{array}$ & Baik \\
\hline
\end{tabular}

Berdasarkan tabel 2 hasil penelitian status kesehatan perilaku hidup bersih dan sehat (PHBS) didapatkan bahwa pasar ciputat dalam kategori kurang, sedangkan pasar modern BSD dalam kategori baik. Lebih rincinya dapat dilihat pada tabel 2.1

Tabel 2.1Skor Penilaian Perilaku Hidup Bersih Dan Sehat (PHBS)

\begin{tabular}{lcc}
$\begin{array}{l}\text { Komponen } \\
\text { penilaian }\end{array}$ & \multicolumn{2}{c}{$\begin{array}{c}\text { Skor } \\
\text { Penilaian }\end{array}$} \\
\hline $\begin{array}{l}\text { Pasar } \\
\text { ciputat }\end{array}$ & $\begin{array}{c}\text { Pasar } \\
\text { modern } \\
\text { BSD }\end{array}$ \\
\hline $\begin{array}{lcc}\text { Dan Pekerja } \\
\text { Pengunjung }\end{array}$ & 900 & 1350 \\
\hline $\begin{array}{l}\text { Pengelola } \\
\text { Keterangan : }{ }^{*} \text { Memenuhi Syarat }\end{array}$ & 500 \\
\hline
\end{tabular}

Berdasarkan tabel 2.1 hasil skor penilaian perilaku hidup bersih dan sehat (PHBS) pada 3 komponen penilaian didapatkan bahwa status kesehatan perilaku hidup bersih dan sehat pada kedua pasar memenuhi syarat pada 1 komponen penilaian yaitu pengelola.

\section{Pembahasan}

\section{Sanitasi}

Penilaian dilakukan melalui observsi, pengukuran langsung dan wawancara tidak terstuktur pada variabel sanitasi didapatkan 
skor hasil pada pasar ciputat yaitu 1484 dengan kategori kurang dan pada pasar modern BSD skor yang diperoleh adalah 2500 dengan kategori baik.

Pada pasar ciputat yang masih menjadi masalah yaitu pada toilet tidak tersedia tempat cuci tangan dan sabun, serta tempat sampah yang tidak tertutup, setiap kios/los belum tersedia tempat sampah. Tempat sampah di pasar ciputat belum terbuat dari bahan yang kuat, kedap air dan mudah dibersihkan rata-rata masih terbuat dari keranjang yang terbuat dari anyaman bambu, tempat pembuangan sementara masih menjadi tempat perindukan vector dari hasil observasi masih terlihat banyaknya larva lalat disekitar gundukan sampah, menurut hasil wawancara dengan pengelola pasar dan pedagang desiinfeksi pasar belum pernah dilakukan sama sekali.

Pada komponen sanitasi yaitu air bersih, kedua pasar masih memiliki masalah yang sama yaitu pengujian air bersih dan air limbah belum dilakukan secara rutin selama setiap 6 bulan sekali, hal ini sesuai dengan penelitian yang dilakukan muthia dkk pada pasar Towoe di tahuna kabupaten kepulauan sangihe air limbah di pasar Towoe juga belum dilakukan pengujian kualitas air limbah sehingga limbah cair menjadi bau khususnya dari los pasar ikan (7).

Pada aspek sanitasi komponen kamar mandi dan toilet terjadi kesimpangan anatara pasar modern dan pasar serpong. Pada pasar serpong tidak tersedianya empat cuci tangan dan tempat sampah yang tertutup apabila tidak tersedianya hal tersebut dapat berisiko menimbulkan kontaminasi tinja dari tangan manusia yang tidak mencuci tangan setelah buang air besar dan terjadi kontaminasi silang berbagai penyakit antara pedagang dan pembeli. Penelitian ini sejalan dengan yang Kurnia Nurcahya,et al pada pasar dikabupaten jember yaitu pasar tanjung jember, kamar mandi dan toilet di pasar harus memiliki tempat cuci tangan yang dilengkapi sabun sehingga pedagang atau pengunjung yang selesai buang air besar bisa mencuci tangannya air (8). Di dalam kamar toilet harus tersedia sabun, jika tidak tersedia hal ini sangat berisiko menimbulkan kontaminasi tinja dari tangan manusia yang tidak mencuci tangan dengan sabun setelah buang air besar (6).

Pada komponen pengeloaan sampah kedua pasar ini memiliki masalah yang sama yaitu setiap kios/lorong/los tidak tersedia tempat sampah basah dan kerding dalam aspek sanitasi hal ini menjadi penting karena komonen pengelolaan sampah yang tidak baik berpengaruh terhadap pencemaran lingkungan dan menjadi penyebaran penyakit, Hal ini sejalan dengan Hasil penelitian Purnama S,G. et all mengenai kualitas mikrobiologi dan hygiene pedagang lawar dikawasan pariwasata kabupaten gianyar, bali (8). Kebersihan lingkungan sepeti sampah yang berserakan dilantai karena tidak adanya tempat sampah disetiap kios/lorong, dan adanya binatang penular penyakit/vector berpengaruh terhadap cemaran bakteri. Penelitian lainnya di brazil juga menemukan bahwa faktor sanitasi berpengaruh terhadap cemaran E.coli. (8)

Drainase dalam arti pembuangan massa air secara alami, drainase yang baik adalah limbah cair yang mengalir lancar dan tidak bangunan diatas saluran, namun pada saat observasi pasar serpong pada bagian limbah cair tidak mengalir lancar hal ini mengakibatkan penumpukann limbah pada drainase tersebut sehingga menjadi tempat perindukan berbagai vektor. penelitian ini sejalan dengan penelitian Siahaan, diketahui drainase untuk pasar simpang limun, bahwa selain tidak ditutup dengan kisi-kisi, drainase yang ada merupakan saluran terbuka. Ditemukan adanya sampah pada saluran tersebut yang menghambat aliran air limbah yang dibiarkan begitu saja, makan akan menjadi tempat perindukan bagi vector misalnya nyamuk dan lalat yang dapat menularkan berbagai penyakit (9).

Binatang pembawa penyakit (Vektor) yang dijumpai pada lingkungan pasar sangat merugikan dan menganggu kenyamanan . kedua pasar ini memiliki masalah yang sama yatu masih terlihatnya tikus disekitar lingkungan, dan bahan pangan masih dihinggapi oleh lalat, kecoa. Dipasar, angka kepadatan tikus harus nol yang artinya tidak boleh ada satupun tikus di pasar (6) hasil ini sejalan dengan hasil wawancara yang dilakukan Nurcahaya dalam identifikasi sanitasi pasar tanjung dikabupaten jember kepada pedagang, pedagang lantai satu pernah melihat tikus berkeliaran disekitar 
pasar. Hal ini tidak sesuai dengan ketentuan yang ada dalam pedoman penyelenggaraan pasar sehat. Tikus tidak boleh ada dipasar karena selain menyebarkan penyakit, tikus juga dapat merusak barang dagangan yang ada dipasar, (10).

Pada komponen kualitas makanan, makanan yang dijual di pasar tidak boleh mengandung bahan berbahaya seperti pengawet, borax, formalin, pewarna textil yang berbahaya. Bahan-bahan berbahaya tersebut jika tertelan akan menimbullkan gangguan antara lain keracunan dan kanker. Makanan yang mengandung rhodamin B berwarna merah terang dan terasa pahit bila dimakan. Rhodamin B merupakan zat pewarna yang toksik. Gejala keracunan dari rhodamin B ditunjukan adanya iritasi pada paru-paru, tenggorakan (11).

Desinfeksi adalah menghancurkan atau membunuh kebanyakan organisme pathogen pada benda dengan menggunakan campuran zat kimia cair. Desinfeksi dipasar penting dilakukan secara berkala minimal 1 hari dalam sebelum agar bakteri atau jamur penyebab penyakit dapat dibasmi sehingga tidak menyebarkan penyakit kepada pedagang ataupun pengunjung pasar. Namun hasil observasi pasar serpong belum melakukan desiinfeksi pasar secara ruin, Berdasarkan hasil penelitian dilakukan Kurnia Nurcahya et al. pasar tanjung melakukan desinfeksi berupa fogging hanya pada saat terdapat wabah demam berdarah, jelas desinfeksi secara berkala merupakan tindak pencegahan agar suatu penyakit tidak pernah terjadi dan menyebar di pasar (10).

\section{Perilaku Hidup Bersih dan Sehat}

Penilaian dilakukan melalui observasi dan wawancara yang tidak terstukur pada variabel perilaku hidup bersih dan sehat (PHBS) terdiri dari pedagang dan pekerja, pengunjung dan pengelola dan didapatkan skor hasil pada pasar ciputat yaitu 1400 dengan kategori kurang dan pada pasar modern BSD sector yang diperoleh adalah 2350 dengan kategori baik.

Bagi pedagang karkas daging/unggas, ikan dan pemotong unggas harus menggunakan alat pelindung diri sesuai dengan pekerjaanya (sepatu,boot, sarung tangan, celemek, penutup rambut dII) hal ini berguna untuk menjaga keselamatan pedagang saat bekerja serta menjaga bahan pangan agar terhindar dari kontaminasi dari pedagang, berdasarkan hasil observasi di pasar ciputat dan pasar modern BSD, pedagang dan pekerja karkas daging/unggas di kedua pasar tersebut sudah menggunakan alat pelindung diri

Pada hasil observasi pada pasar ciputat yang masih menjadi masalah yatiu pedagang dan pekerja belum berperilaku hidup bersih dan sehat dilingkungan pasar, hal ini terlihat pada hasil observasi peneliti menunjukkan bahwa pedagang saat berdagang merokok, membuang sampah sembarangan, meludah sembarangan dapat berpengaruh terhadap kesehatan. Hal ini sejalan dengan penelitian Tatang Roni, bahwa perilaku masyrakat yang tidak bersih dan sehat akan berpengaruh terhadap kesehatannya (12).

Dalam kepmenkes RI no 519/Menkes/SK/VI/2008, harus ada pemeriksaan kesehatan berkal bagi para pedagang minimal 6 bulan sekali, namun kedua pasar memiliki masalah yang sama yaitu dari hasil wawancara kepada pedagang mereka mengatakan bahwa belum pernah dilakukan pemeriksaan kesehatan secara berkala minimal 6 bulan sekali. Pemeriksaan ini berguna untuk mendeteksi apakah ada pedagang yang menderita penyakit menular sehingga dapat segera diobati agar penyakitnya tidak menyebar dan dapat memantau kesehatan pedagang (6)

Penelitian sejalan dengan Dami, bahwa hasil wawancara peneliti dengan pedagang pasar sentral kota gorontalo , pedagang belum diberlakukannya pemeriksaan kesehatan secara berkala hanya saja memperoleh pelayanan kesehatan dari jasa pekerja keliling yang bukan ti dari medis kesehatan berupa tes tekanan darah dan kemudian diberi upah oleh pedagang pasar sentral (13).

Dalam aspek perilaku hidup bersih dan sehat pengunjung pasar serpong masih memiliki PHBS yang kurang baik yaitu beberapa pengunjung pasar masih membuang sampah sembarangan, merokok dan membuang dahak sembarangan hal ini mengakibatkan berkurangnya estetika tempat diwilayah tersebut, pasar semakin menjadi terlihat kumuh . dan para pengunjung memiliki masalah yang sama untuk kedua pasar yaitu tidak melakukan 
cuci tangan pakai sabun, prasarana pasar pun itu tidak disediakan tempat mencuci tangan hal ini tentu saja dapat memudahkan terjadinya penyebaran penyakit karena manfaat mencuci tangan sendiri yaitu mengurangi risiko diare dan sakit perut, menghilangkan kuman dan bakteri serta mencegah penularan penyakit (13)

Sikap dan tindakan perilaku hidup bersih dan sehat seseorang mencerminkan pada hasil yang didapatkan. Timbulnya permasalahan kesehatan dilingkungan pada dasarnya disebabkan karena kurang kesadaran dari setiap orang untuk melakukan perilaku hidup bersih dan sehat, terjaganya perilaku tersebut dilatarbelakangi oleh beberapa faktor yaitu kemauan dan kesadaran sikap, pengetahuan dan perilaku yang saling berhubungan erat untuk mencapainya derajat kesehatan masyarakat

\section{Kesimpulan}

Berdasarkan hasil penelitian yang dilakukan di pasar ciputat dan pasar modern BSD tahun 2018 mengenai penilaian status kesehatan pada aspek Sanitasi dan Perilaku Hidup Bersih Dan Sehat (PHBS), sebagai berikut :

1. Status kesehatan pada komponen aspek sanitasi dapat disimpulkan dengan nilai maksimum 2880 di Pasar Ciputat didapatkan 51,5\% dengan kategori kurang, sedangkan Pasar Modern BSD didapatkan $86,6 \%$ dengan kategori baik

2. Status kesehatan pada komponen aspek perilaku hidup bersih dan sehat (PHBS) dapat disimpulkan dengan nilai maksimum 3000 di pasar ciputat 46,7\% dengan kategori kurang, sedangkan pasar Modern BSD didapatkan 78,3\% dengan kategori baik

\section{Daftar Pustaka}

1. Peraturan Presiden Republik Indonesia Nomor 112 Tahun 2007 Tentang Penataan Dan Pembinaan Pasar Tradisional, Pusat Perbelanjaan Dan Toko Modern; 2007

2. Depkes RI. Tugas Petugas Kebersihan Tiap Kota. Ditjen PMM dan PL.Jakarta; 2009.

3. Abejegah C., Abah S.O., Awunor N.S., Duru C.B., Eluromma E., Aigbiremolen A.O., Okoh E.C. Market Sanitation: a case study of oregbeni market, Benin-
City, Edo State, Nigeria. Internasional Journal Of Basic, Applied and Innovative Research. IJBAIR; 2(2): 2013; 25-31

4. Bahri, Samsul. Faktor-Faktor Yang Mempengaruhi Sanitasi Pasar Bina Usaha Di Gampong Ujong Kalak Kecamatan Johan Pahlawan Kabupaten Aceh Barat. Fakultas Kesehatan Masyarakat Universitas Teuku Umar Maeulobah; 2014 [Cited 2 desember 2018 pukul 08.45]. Available from:http://repository.utu.ac.id/480/1/BAB $\% 201 \_$V.pdf

5. Kementerian Perdagangan Republik Indonesia. Mendag: Pasar BSD Serpong Acuan Revitalisasi Pasar Percontohan. Pusat Hubungan Masyarakat Kementerian Perdagangan Republik Indonesia: Jakarta; 2013 [Cited 8 Desember 2018]. Available from: https://nanopdf.com/downloadFile/pasarbsd-serpong-acuan-revitalisasipasar_pdf

6. Keputusan No.519/2008 tentang Pedoman Penyelenggaran Pasar sehat; 2008

7. Muthia, Frans dan Odi, Harvani. Identifikasi sanitasi Pasar Towoe di Tahuna Kabupaten Kepulauan Sangihe. Universitas Sam Ratulangi: Fakultas Kesehatan Masyarakat; 2017 [Cited 6 desember 2018 Pukul 11.27]. Available from:

https://ejournalhealth.com/index.php/med kes/article/view/245

8. Purnama,S,G dkk. Kualitas Mikrobiologis dan Hygiene Pedagang lawar dikawasan pariwisata Kabupaten Gianyar, Bali. Jurnal Kesehatan Lingkungan Indonesia 16 (2): 2017; 56 - 62

9. Siahaan, Rame Manurita. Tinjauan Sanitasi Pasar Simpang Limun Kelurahan Sudirejo H Kecamatan Medan Kota Kotamadya Medan Tahun 2000. Fakultas Kesehatan Masyarakat, Universitas Sumatra Utara; 2013. Available from: http://repository.usu.ac.id/handle/123456 789/38373

10. Nurcahaya, Kurnia. Dkk. Identifikasi Sanitasi Pasar dikabupaten Jember (Studi Pasar Tanjung Jember). Jember: Fakultas Kesehatan Masyarakat Universitas Jember; 2013 [Cited 1 Desember 2018 Pukul 13.00]. Available 
from:

http://repository.unej.ac.id/bitstream/han dle/123456789/61850/Kurnia\%20Nurcah ya.pdf?sequence $=1$

11. BPOM. Bahan berbahaya yang dilarang untuk pangan; 2006 [Cited 20 januari 2019], Available from: https://www.pom.go.id/mobile/index.php/ view/berita/139/BAHAN-BERBAHAYA-

YANG-DILARANG-UNTUK-

PANGAN.html\%20.\%202006

12. Tatang Roni S, Ruhmawati Tati, Denny Sukandar. Hubungan Pendidikan dan Penghasilan dengan Perilaku Hidup Bersih dan Sehat. Jurnal Kesehatan Lingkungan Indonesia Vol.12, No 1: 2013

13. Dami T, Riwan. Studi Sanitasi Lingkungan Pasar Sentral Kota Gorontalo. Universitas Negeri Gorontalo :Fakultas IImu-IImu Kesehatan dan Keolahragaan; 2014 [Cited 6 desember 2018, 21.07]. Available from: kim.ung.ac.id/index.php/KIMFIKK/article/ download/10873/10750 